KPИТИKA

[ Б[БЛ]ОГРАФ]

\title{
Review of the book
}

\begin{abstract}
«Poland-Holy See, on the history of mutual relations in the 100th anniversary of the renewal of diplomatic relations», edited by Wojciech Biliński, in cooperation with Piotr Samerek and Hubert Wajs, published by the Ministry of Foreign Affairs, Department of Public and Cultural Diplomacy, first edition, Warsaw 2019. (The publication is non-commercial and is not intended for commercial trading)
\end{abstract}

Dr. Ewa Sałkiewicz-Munnerlyn chargé d'affaires at the Holy See in the years 15.08.1993-26.11.1963 and 17.01.1994-09.05.1994.

The book consists of an introduction, $\mathrm{X}$ separate articles, an annex, selected literature and illustration sources. Before the introduction, there is an entry from the editors in which we can read that "the publication of the Ministry of Foreign Affairs is intended for a wide audience not only in Poland." On the last page, however, that "The publication is non-commercial and not intended for commercial trading." The question is, how can a wide audience see this publication if it cannot be bought? Who can read a book that is not widely accessible?

The book has an introduction by the Minister of Foreign Affairs of the Republic of Poland, Jacek Czaputowicz, the book is published by the Ministry of Foreign Affairs, so it would seem logical to invite for a cooperation such persons as for example: the personal papal secretary, Cardinal Stanisław Dziwisz, longtime ambassador to the Holy See, Prime Minister Hanna Suchocka, Józef Kowalczyk, the first nuncio of the Holy See in Poland after changes in 1989, former Polish ambasador to the Holy See, Stefan Frankiewicz and many others.

Not to mention my humble person, as the editor of this book Mr. W. Biliński took office in May 1994 after me, as chargé d'affaires. Whereas amb. Henryk Kupiszewski was not in Rome due to illness from July 1993 until 26.11.1993 and from January 17, 1994 until his death on April 3, 1994. All this time, the Embassy of the Republic of Poland at the Holy See has been working quite well under my direction as the chargé d'affaires from 15.08.1993 to 26.11.1993 and from 17.01.1994 to 09.05.1994.

Due to the fact that the ambassador at the Holy See is also accredited at the Order of the Knights of Malta, it would be interesting to present this aspect of his activity, which is missing in the book.

Regarding chapter III, author Wojciech Biliński (Ministry of Foreign Affairs of the Republic of Poland), Representatives of the Polish-Lithuanian Commonwealth at the Holy See in the 16th18th century, p.135, speaking about the marquis Tommasso Antici, as Poland's first permanent representative to the Holy See in the rank of chargé d'affaires, it would be good to mention that, in 1768 he obtained the Polish indigenate (naturalization), which meant in the Polish-Lithuanian Commonwealth, the grant of nobility to foreign nobles. To grant naturalization, a foreign noble had to submit proof of their service to the Republic, together with proof of nobility issued by a foreign court, swear an oath of allegiance, and buy land. It was granted by the King, after 1641 it was only valid with approval of the General sejm (parliament).

As far as the chapter IX is concerned, author Marek Pernal (Ministry of Foreign Affairs ofthe Republic of Poland), Diplomatic relations between Poland and the Holy See after 1989, it seems that there is an error on 
p.330. Prelate Marian Rola, rector of the Polish Pontifical college in Rome, whom I had honor and privilege to know, served in the capacity of the canonical counsellor not in 1990-2000, but according to the List of Diplomatic Corps (July 1993), from 17 april 1991.

There is also a gap on the same p.330, when author says who led the Polish Embassy to the Holy See after the death of amb. H. Kupiszewski on 3rd April 1994 in Warsaw, but forgets to mention the name of dr Ewa Sałkiewicz, the chargé d'affaires before, it means from August 1993 to May 1994.

And on the same page 330, about presenting the letters of introduction by Mr. W. Biliński in the Secretariat of State...According to the diplomatic protocol, the chargé d'affaires, presents the letter of introduction not in the Secretariat of State, but to the minister of foreign affairs, where she/he is accredited. I did it personally to the Minister of Foreign Affairs of the Holy See, card, Jean-Louis Tauran. Article 19 of the Vienna Convention on Diplomatic Relations (1961) deals with the absence of the head of the diplomatic mission. The Article states that if the post of the head of mission is vacant, or if the head of the mission is unable to perform his duties, a chargé d'affaires ad interim shall act provisionally as the head of the mission. The chargé d'affaires ad interim shall be notified by either the head of the mission or by the Ministry for Foreign Affairs of the sending State to the Ministry for Foreign Affairs of the receiving State or such other body as may be agreed.

Also small correction from the p.330, regarding the offices of the Polish Embassy to the Holy See, first located at Borgo Santo Spirito 16, int.4. It was not a property made available to the Polish side by the Vatican, but Polish state was renting it form the Jesuits.

At the end, three general remarks. First, the surname index is missing. Second, in the selected literature, name of authors are mentioned together with other types of documents. Third, in the table of illustrations, they are among the authors of illustrations Wikimedia Commons. Wikimedia or Wikipedia are not considered to be a reliable scientific source of information. 